\title{
Towards a pedagogy of strangeness
}

\author{
Exploring the potential of strangeness for foreign language \\ Education
}

\section{Katja Frimberger}

\begin{abstract}
Engagement in depth with a foreign language is a challenging experience. Within the experience, and at a crucial interface - where familiar perspectives are questioned, deconstructed and re-considered - lies an area that I term 'strangeness'. The word strange has a range of meanings; "outside of", "alien", "different", "unusual", "exceptional to a degree that excites wonder or astonishment" (OED 1989). The strangeness that resonates within a foreign language reflects several of these definitions; it is multi-faceted, unpredictable, even sometimes unfathomable, but ultimately, I hope to show that it has exciting, life-enriching potential that, like the latter definition above, will elicit wonder and astonishment. This article proposes a 'pedagogy of strangeness' in foreign language education that aims to provide some ideas and praxis to help students unlock more of the enriching potential that the study of the subject holds. The term 'predictable strangeness' is used critically to describe the conventional approach to teaching language and culture. The idea of 'unpredictable strangeness' is employed to elucidate the subtleties that lie especially within an ethnographic approach to foreign language teaching. Theatre and drama concepts that substantially employ strangeness within their work will be shown to have particular relevance to my article.
\end{abstract}

Contradictions are our hope! (Brecht 1964: 47)

\section{Predictable Strangeness}

Taking my lead from the criticism of dominant, technicist approaches to the teaching of foreign languages and cultures in second and higher education (cf. Phipps \& Gonzales 2004), I propose to refocus strongly on the relational, volatile and non-packagable aspects of foreign languages which require more creative approaches.

According to Michael Byram - a researcher in cultural studies - foreign languages in most secondary institutions are still taught as linguistics plus culture. Language students' activities, he claims, are mainly concentrated on 
the acquisition of vocabulary and the general structure of the language (Byram \& Fleming 1998: 5). Teaching of culture - described as "background studies" in the UK, "Landeskunde" in Germany or "civilisation" in France" (ibid.) -is mostly a passive, receptive activity involving historical or sociological information selected and provided by the teacher and contained in the respective teaching material.

A typical example of the material would be a textbook (English G 2000) I have used to teach English in a German secondary school to 14-year-olds.

Looking at a chapter on Scotland with a glossy tartan pattern layout, there is a beaming redhead by the name of McPherson, the Scottish national flag, cheering rugby fans urging on their team against the 'auld enemy', a bagpipe band and a recipe for shortbread. Many other examples could be shown and I would venture that most would be felt by the citizens of the target culture to be at the best humorous, at the worst offensive.

Culture, as portrayed in my textbook (and in so many others of the type), is shown as an eclectic choice of more or less interesting historical and sociological facts (and well-worn 'auld' clichés) lumped together to present the 'exotic' differences of the target language community. It focuses on the student mostly as a consumer needing language skills and a packagable knowledge of some customs and key literature. Seen this way, learning about culture is foremost a cognitive process available in light, "off-the-shelf packages" (Phipps \& Gonzales 2004: 57), ignoring the more asymmetric, more veiled social reality of the language to be learned ${ }^{1}$.

Because of the demands of the global labour market, the way of teaching culture and learning languages today is in danger of becoming commoditised and therefore "detached from human ways of being" (ibid. xv).

Culture, as thus taught - essentially prescriptive and not accounting sufficiently for the unforeseeable - I describe as predictable strangeness.

\section{Unpredictable Strangeness}

Culture is never static. It is volatile and unpredictable, in constant evolutionary flux, and should be seriously taken into account when dealing with new intercultural challenges. Ever-increasing cross-cultural contact with 'abroad' has introduced more complexity into modern culture and living. Languages are not a "key sign of belonging" (ibid. 2004: 18) anymore; home and abroad are becoming increasingly obsolete terms in today's multilingual societies. As social change, in the form of internationalisation and globalisation, create the conditions for taking the cultural dimension serious again (cf. Byram \& Esarte-Sarries 1991: 8), the question emerges of how to attain a fluency ${ }^{2}$ in living within these diverse social realities (cf. Phipps \& Gonzalez 2004: 27).

\footnotetext{
${ }^{1}$ Arguing from a higher education perspective, Phipps \& Gonzales (ibid. 8ff) also criticise the way foreign languages are often marketed as adjuncts to other non-language degrees.

2 See European Language Proficiency Survey (cf. Coleman 1998).
} 
The European Language Proficiency Survey strongly reminds us how crucial the aspect of 'living fluently' is: this project, carried out in 1993 (replicated with similar results the following year) found that among 3,000 students from the UK and Ireland, up to 30\% returned from their year abroad with a more negative view of the target language community than those who had not yet undertaken residence abroad (cf. Coleman 1998). Coleman found that those negative changes in perception were mostly on an interpersonal level, and more likely to reflect the students' subjective experiences rather than detached observation.

Based on the findings of the survey, Phipps \& Gonzalez (2004) emphasise the importance of pedagogically preparing the foreign (and partly unforeseeable) experience in ways that do not lead to resistance and rejection but to an enrichment of students' experiences. Coleman (1998) also concludes that apart from material and practical preparation it is also necessary to prepare students psychologically and, most importantly, interculturally for their year abroad.

The challenge seems to be to examine more closely the relational aspects of "living between cultures" (ibid.) that involves the acknowledgement of languages as a vivid reflection of the whole human experience. Taken this diverse potential into account, my question is: How can we relish, harness and live with strangeness? - or, as Julia Kristeva asks, "Shall we be, intimately and subjectively, able to live with the other, to live as others, without ostracism but also without levelling?" (Kristeva 1991: 2). According to Byram, living with the other requires an understanding attitude to different ways of being "as they're embodied in the language to be learnt" (Byram \& Fleming 1998:12). These ways of being or, as Fels calls it, the "multiple worlds" inherent in a language, not only resonate with the "worlds of experience, relationships, the environment etc. but also occur in different forms; language can be spoken, written, danced into being" (cf. Fels \& McGivern 2002: 22). Developing language fluency thus entails more than the accurate use of a linguistic system; it involves touching the otherness - "brush by it, without giving it a permanent structure" (Kristeva 1991: 3) -, acknowledging the vividness, even the ephemeral nature of human experience. Crossing human borders also involves touching the stranger within ourselves: "the hidden face of our identity, the space that wrecks our abode, the time in which understanding and affinity founder" (ibid. 1). Bhaba (1992) describes this alienation as "an interrogative space of psychic ambivalence and social contingency" (quoted in Kramsch 1996: 59) which holds the opportunity to pause, reconsider and change concepts of self and otherness. Acknowledging these forms of unpredictable strangeness consequently requires a focus on procedures rather than on product-oriented skills and abilities (cf. Phipps \& Gonzales 2004: 2f).

\section{$3 \quad$ Teaching Unpredictable Strangeness}

The question naturally emerges how language teachers can actually equip their students for this dynamic engagement with unpredictable strangeness 
and enable them to embrace the transformative power it can have on their lives. Far more than just providing factual knowledge about the target language community, cultural education has to provide "the creative and experiential foundations" (Phipps \& Gonzalez 2004: 114) that allow for the development of self-reflection in order to harness the strangeness that underlies active human encounters. The teacher's challenge therefore is not just to equip students with performative language skills and to provide comprehensive information on the foreign country, but rather to encourage learners to investigate themselves the strangeness in and around them - here, in their immediate environment, as well as abroad.

Adopting an ethnographic perspective could help students develop this inquiring attitude rather than consumerist views of culture. Ethnography regards culture as something that is dynamically changing - it is, as Cunico defines it "localised, heterogeneous and fragmented rather than national and monolithic" (2005: 23). Aiming to study a language community's cultural practices by living within it, ethnography involves methods of observation and description and written (or audio-visual) accounts guided by social and cultural theories.

With the aim of living between, of understanding one while belonging to another culture, an ethnographic perspective holds the potential to initiate a critical engagement with multiple concepts of otherness - different thoughts, values and historical visions (cf. Phipps \& Gonzales 2004: 120) - thus weaning away the student from an ethnocentric view of other peoples and cultures.

Consequently, students should be encouraged to make connections between their own-experienced cultures and those of the groups being studied, thus focussing on 'thick descriptions' (cf. Geertz 2003) where detailed observation, rather than subjective response could be combined with interpretation.

Barro et al. (1998: 84ff) gives an example: Instead of relying on the thin description "French children are not allowed to leave the dinner table early", a thick description is more likely to open up an inquiry. Possible questions, he suggests could be "How do meals end?", "Do meals at different times of the day end in different ways?", or "What is the home context within which these meals are observed?" and so on.

Asking these questions ultimately replaces the binary 'us versus them' approach, e.g. the hard working Germans versus the polite English, with an open discourse that focuses on individuals.

Encouraging students to inquire into culture as a whole, Barro (ibid.) gives examples for mini-fieldworks that could result from this ethnographic view on language learning: Positing an ethnography course as part of a language degree, one of Barro's first exercises - to make the familiar strange - involves students in describing their daily journey to university as if they were complete strangers. He asks them to focus on how they manage the space between themselves and others in a crowded train or bus - realisations that are later integrated in the course's teaching unit on social space. Through detailed observation and description, students are made conscious about the social knowledge required 
to manage even the most mundane everyday activities and social relationships.

Combining intellectual and experiential processes (cf. Roberts et al. 2001: 3 ), ethnographic principles thus become attractive for language education "when it takes seriously the cultural dimension and regards communication and interaction as valid objectives within the discipline" (Byram \& Fleming 1998: viii).

\section{The Realm Beyond}

To be able to develop an inquiring, ethnographic attitude and escape the "captivities of culture" as Phipps \& Gonzalez (2004: 168) describe them, language teaching should also consider cultural identity as an unstable phenomenon.

Kramsch (1996: 4) reminds us how easily "I could have been you or you could have been me", depending on chance circumstances that might easily have been interchangeable. Acknowledging this instability of fixed cultural concepts, language teaching would thus not only aim at reconsidering false or stereotyped assumptions, but also acknowledge "ourselves as foreigners, unamenable to bonds and communities" (Kristeva 1991: 1).

This demand of foreign language education is crucial for a pedagogy of strangeness because it requires teaching approaches to take this instability into account - and open up possibilities for the exploration and negotiation of imaginary cultural concepts.

Transcending the limitations of the classroom and allowing for inquiry into human situations and cultures in ways that are not possible in real life (cf. Byram \& Fleming 1998: 144), drama could provide this explorative space.

Concepts of culture negotiated in the 'safety' of the fictional world and generating material for analysis could enrich the ethnographic approach with a new dimension beyond (cf. Byram \& Fleming 1998). Situations can be consciously deconstructed and replayed and behaviour scrutinised through embodied reflection. As a consequence, drama can initiate exchange, negotiate outcomes and test assumptions leading to what might be best described as a self-reflective 'embodied ethnographic habit'. Drama concepts which provoke the individual's embodied reflection and negotiation of the commonplace could prise open challenging spaces to 'sort out' unpredictable strangeness.

\section{Brecht: Making Strange of the Familiar}

What appealed to most of us [...] was strangeness and incomprehensibility. Our real element was the element of chaos challenging our simple minds to sort it out. (Brecht 1964: 20)

Whilst studying Bertolt Brecht, I found that his theatre and culture critique connected to those critical voices in foreign language and cultural studies today that call for a renewed, creative and experiential foundation in the field. I 
also discovered in Brecht's writings his ethnographic approach and his ideas demanding a focus on the actor as an active social agent within a multi-faceted world.

In order to provoke his actors and audiences to rethink stereotyped concepts of society and reflect on their own role and responsibility within the world, Brecht sought out and generated strangeness to a degree that would question and even break traditional, fixed cultural perspectives. This process of 'making strange', intended to turn both spectator and actor into active observers, was applied to all moments shown on stage. It involved actors, stage technique, dramaturgy and music, and created what Brecht called "the three threads of epic theatre - playing in quotation marks, the portrayal of complex processes and creating a detached unemotional style" (Brecht 1964: 17). The style of acting in Brecht's theatre, the playing in quotation marks, involved what Brecht called "Gestus" (ibid. 42). The performers, holding themselves remote from the character portrayed, are just showing the characters' behaviour, relatively unemotionally, "perfectly sober", "in a matter-of-fact way" (ibid. 15), thus maintaining the make-believe of the situation and allowing for inquiry into the subject matter. Strangeness within the gestic style of acting was created by speaking the character as if in the third person or in quotation marks, including all the sub-text the actor himself brought to the text. These rehearsal techniques evoked alienation and helped the actor develop a habit of inquiry into the character which, despite being of an intellectual nature, wouldn't deny emotional engagement. On the contrary, in the first stages of rehearsal actors were urged to get acquainted with the play and their respective characters. In the second phase, they were to empathise with their characters, seeing the world through their eyes. In the third phase, they distanced themselves from their role. At this final stage, actors were supposed to look at the characters as strangers - from outside of their own and society's point of view. To support this transition from empathy to the distancing phase, Brecht's third-person-exercise - one of many exercises evoking alienation - served an important purpose. Stage directions such as "said the man" or "said the woman" were read out loud and these enabled the actor to distance and develop a detached attitude towards the character. Again, the aim was to open up inquiry; the exercise wasn't intended to deny emotional engagement but to "open up the view that the actor's emotion doesn't have to coincide with the character's" (Thomson 2000: 105). The constant deconstruction of facts and assumed necessities within the playing of a character brought forward what Brook (1969, quoted in Thompson 2000: 106) calls Brecht's idea of the "intelligent actor". This actor requires a deep knowledge of theatre craft and considerable political education to be able to act out the complexity of a character within his social constraints (ibid.).

In order to observe one must learn how to compare. In order to compare one must have observed. By means of observation knowledge is generated; on the other hand knowledge is needed for observation. (Brecht 1961: 270) 
Brecht thought it indispensable that actors would develop an ethnographic habit and become what I would describe as 'acting/actor ethnographers.' The intelligent actor was supposed to use strangeness as an artistic device in order to show human existence as multi-faceted and ultimately dynamically embedded in social reality.

In one of Brecht's rehearsal exercises - intended to sensitise actors to the potential of everyday strangeness - he asked his players to be observers of common domestic scenes such as this one: A group of women and a group of men are folding linen - others watch the scene interrogating:

Do women and men do things differently? Why? Is doing things with linen a female thing? Who determines that? etc. (Brecht 1964: 122)

Everyday attitudes were deconstructed and questioned, opening up a view beneath the surface of the ordinary. The tameness of this domestic situation was also combined with disruptive elements such as a wild quarrel by the women defending their husbands. The orderliness of the folding and the disorderliness of the speaking evoked strangeness and gave a further insight into the complexity of human transactions (cf. ibid. 129).

Similarly, foreign language students should be enabled to build up a critical habit of inquiry into familiar concepts of culture. This would lead to the deconstruction of the obvious and expose underlying complexities. They could also - just as Brecht's actors were - be encouraged to use their own sub-texts (their life experiences, values, etc.) to make sense of the revealed strangeness and thus become Brechtian 'double agents' - rooted in and valuing their native reality and at the same time infiltrating a new, foreign one. What Chaikin says about Ekkehard Schall, the 'ultimate' Brechtian actor, illustrates the point:

I never believe he is the character by name. Nor do I believe that he is playing himself. He performs like a double agent who has infiltrated two worlds. (Chaikin quoted in Thomson 2000: 106)

In the same way, foreign language students, enabled to travel as 'double agents' in between native and foreign words and worlds, could open up spaces for thought and questioning. They may "find laughter and loveliness" but could also be empowered to "ask questions about cruelty and oppression" (Phipps \& Gonzales 2004: 168).

\section{Bringing Emotion Back into the Equation}

The attitude of inquiry - the double agency - that Brecht tried to instil in his actors was of an intellectual nature, but at the same time - as it is often assumed - didn't deny the actors' or audiences' emotional engagement. As Carl Weber, Professor Emeritus of Drama and Brecht's former directing assistant and dramaturg at the Berliner Ensemble reminds us (referring to the scene in "The Mother", where Vlassova receives the news of her son's execution): 
It was emotional beyond all expectations; there was hardly a performance without an audience gasping and openly in tears during the scene. (Weber 2006: 180)

Aiming to allow for inquiry into emotions, not just to stimulate unreflecting empathy into the characters of a play, Brecht saw reasoning and emotion as inseparable (cf. Brecht 1964: 162). Also, modern neurology suggests (cf. Damasio 2000) that feeling and thinking are not separate entities. A feeling which might be directly located in the body has a corresponding thinking part and can therefore act as a "quantifier of experience" and influence our decision-making (cf. Bacon 2006: 140). To become what Phipps \& Gonzales call an "intercultural being", able to "move through words, smells, sights and tastes" (Phipps \& Gonzales 2004: 168), it is important to understand and explore the crucial role our feelings play in the construction of meaning.

In developing a pedagogy of strangeness, drama approaches that allow conscious, embodied inquiry into emotions should therefore be included. The stimulation of mere emotion- which Brecht criticised - should not be the main objective. The work of two researchers follows this particular experiential route. 'Performative inquiry', developed by performance arts educator Lynn Fels, is an interdisciplinary mode of learning and research which acknowledges and explores students' emotional reality within drama; 'performance ethnography', suggested by Jane Bacon (2006) is a research methodology in the field of drama education and, like performative inquiry, is underpinned by the enactivist view that only through body and mind interaction meaning-making can be achieved (cf. Bacon 2006: 139ff). This leads to researcher and participants negotiating an embodied research language. As procedural approaches aiming at self-reflexivity, performance ethnography as well as performative inquiry encourage researchers/teachers to think critically and responsibly about their own roles and expectations within the drama.

To give an example: Fels' role drama "Find Ourselves on a Map" created for a conference in 1995, reflects her expectations of the drama - the moments where imagined realities clash and open up spaces for re-orientation and learning (cf. Fels 1998: 31ff). Underpinning her journey of inquiry were questions such as:

How do we create community-place in an art environment given only our memories, our anticipation and our present actions/interactions? Could we create, in sixty minutes, a community that is ours? ... a place to map on the landscape? (ibid. 31).

Intending to create a "space on the edge of the ocean in the shelter of the mountains" (ibid.), Fels spread out a blue sheet on the floor and asked the group to pile cardboard boxes into a mountain range. As Fels, the facilitator, starts to move the ocean further from the group's mountain range to create a strip of land, there is protest - strangeness has unfolded its potential. A woman defends her image of the landscape in which the mountain comes down to the edge of the sea. Fels moves the sea back, accommodating and admiring the woman's independent imagination. When later in the role drama, Fels again 
tries to regain control of the situation that has unfolded unexpectedly, she has to reconsider her action again. By taking down the boxes from the mountain range and instructing the group to build houses for a community with them, protest arises: the group is accusing her (in role) of abusing their land and clear-cutting their forests. Again strangeness has unfolded its potential and a space for self-reflection has opened: "That's what it is to destroy somebody's land without thinking of others" (ibid. 32). Through dramatic exploration, participants were invited into creative spaces of intercultural dialogue, negotiation and interaction that inspired thinking beyond the walls of the classroom and which emerged into "space moments of learning" (Fels \& McGivern 2002: 21) or what Axtman (2002: 82) calls "transcultural recognition". Fels' feeling of guilt/shock/shame when intruding into the other's space opens up an inquiry into the emotional dimension; "How did I feel when this moment occurred? How did you feel?" (Fels 1998: 32).

Bacon and Fels suggest similar creative methods in order to reflect this body/mind dimension of performance. Reflection is, for example, stimulated in the form of group discussions, leading questions or the replaying of single actions or scenes. Referring to Fels' experience of the 'intrusion of space', reflection could specifically focus on bodily-felt issues of personal space: "How is the body reacting to space, to nearness, to distance? What does personal space mean to you? In general how close do you want to get to other people?" (Axtmann 2002: 47). Given the experiential nature of this inquiry and the individual responses that could result from it, reflection might take on a language which can "speak from, through and with the body" (Bacon 2006: 136). Responses might be given and shared in the form of poems, drawings, journal entries and acting, thus documenting the bodily-felt dimension of the inquiry. In the light of the other's reactions, assumptions are deconstructed and reassembled aiming to negotiate a verbal and non-verbal language that makes meaning of the space-moment reality.

Practicing this art of relativism within and outside the drama, students might also learn not only to take into account real-life complexity but could be challenged to reflect on and possibly even be enriched by it. Introducing drama concepts that consciously generate strangeness and stimulate inquiry into intellectual and emotional areas of human being, foreign language education could then provide the "creative and experiential foundations" (Phipps \& Gonzales 2004: 114) that allow for a critical, self-reflective engagement with unpredictable strangeness.

\section{Summary}

I opened this article by defining predictable strangeness as a commoditised approach to the teaching of language and culture. Counter-proposing a pedagogy of strangeness based on the idea of unpredictable strangeness, I suggested an ethnographic approach which considers the relational and volatile aspects of language learning. Looking at drama concepts that could 
encourage an inquiring attitude into familiar and possibly fixed cultural concepts, I have shown that Brecht, within his actor training, stimulated active intellectual inquiry by using strangeness as a concept to question the familiar. Complementing Brecht's approach to theatre and actor training, Fels' performative inquiry and Bacon's performance ethnography acknowledge and explore the influence bodily-felt emotions have on our concept-making. Through reflection, negotiation and struggling for meaning within and outside the drama, foreign language students should be prepared for 'living in between' the unpredictable strangeness that resonates within intercultural encounters. I conclude with the contention that my ideas about strangeness could be useful to open up unusual and rewarding perspectives in foreign language education leading to new levels of intercultural awareness and enjoyment - what Phipps (at the Bundeskongress GMF in Leipzig, 2008) described as "real, messy languaging."

\section{Bibliography}

Axtmann, Ann (2002): Transcultural Performance in Classroom Learning. In: Bräuer, Gerd (ed.): Body and Language: Intercultural Learning through Drama. Westport: Ablex Publishing, 37-49

Bacon, Jane (2006): The Feeling of the Experience: A Methodology for Performance Ethnography. In: Ackroyd, Judith: Research Methodologies for Drama Education. Stoke on Trent: Trentham Books, 135-155

Barro, Ana; Jordan, Shirley; Roberts, Celia (1998): Cultural Practice in Everyday Life: the Language Learner as Ethnographer. In: Byram, Michael \& Fleming, Michael (eds.): Language Learning in Intercultural Perspective. Approaches through Drama and Ethnography. Cambridge: Cambridge University Press, 76-97

Bhabha, Homi (1992): Post-colonial Authority and Postmodern Guilt. In: Grossberg, Lawrence; Nelson, Cary; Treichler, Paula (eds.): Cultural Studies. London: Routledge, 56-66

Bräuer, Gerd (ed.) (2002): Body and Language: Intercultural Learning through Drama. Westport: Ablex Publishing

Brecht, Bertolt (1964): Brecht on Theatre. London: Methuen

Brecht, Bertolt (1961): Schriften zum Theater. Über eine nicht-aristotelische Dramatik. Berlin/Frankfurt am Main: Suhrkamp Verlag

Brook, Peter (1969): Der leere Raum (The Empty Space). Hamburg: Hoffmann und Campe Verlag

Byram, Michael \& Esarte-Sarries, Veronica (1991): Investigating Cultural Studies in Foreign Language Teaching. Clevedon, PA: Multilingual Matters

Byram, Michael \& Fleming, Michael (eds.) (1998): Language Learning in Intercultural Perspective. Approaches through Drama and Ethnography. Cambridge: Cambridge University Press 
Coleman, James (1998): Evolving intercultural perceptions among university language learners in Europe. In: Byram, Michael \& Fleming, Michael (eds.) Language Learning in Intercultural Perspective: Approaches through Drama and Ethnography. Cambridge: Cambridge University Press, 76-97

Coleman, James (1996) Studying Languages: A Survey of British and European Students. The Proficiency, Background, Attitudes and Motivations of Students of Foreign Languages in the United Kingdom and Europe. London: Centre for Information on Language Teaching and Research

Cunico, Sonia (2005): Pedagogical Perspectives: Teaching Language and Intercultural Competence. In: Language Learning Journal 31, 21-29

Damasio, Antonio (2000): The Feeling of What Happens: Body, Emotion and the Making of Consciousness. London: Vintage

English G 2000 (1999). Band 3A. Berlin: Cornelsen Verlag, 103-105

Fels, Lynn \& McGivern, Lynne (2002) Intercultural Recognition through Performative Inquiry. In: Bräuer, Gerd (ed.): Body and Language: Intercultural Learning through Drama. Westport: Ablex Publishing, 19-33

Fels, Lynn (1998): In the Wind Clothes Dance on a Line: Performative Inquiry: A (Re)search Methodology. In: Journal of Curriculum Theory 14/1, 27-36

Geertz, Clifford (2003): Dichte Beschreibung. Beiträge zum Verstehen kultureller Systeme. Frankfurt/Main: Suhrkamp

Kristeva, Julia (1991): Strangers to Ourselves. New York: Columbia University Press

Phipps, Alison (2008): Towards a Pedagogy of Air: Opening Lecture at Bundeskongress GMF in Leipzig, 27. April 2008

Phipps, Alison \& Gonzales, Mike (2004): Modern Languages: Learning and Teaching in an Intercultural Field. London, CA / New Delhi: Sage Publications

Roberts, Celia; Byram, Michael; Barro, Ana; Jordan, Shirley; Street, Brian (2001): Language Learners as Ethnographers. Clevedon: Multilingual Matters

Rumpf, Horst (1986): Mit fremdem Blick. Stücke gegen die Verbiederung der Welt. Weinheim/Basel: Beltz Verlag

Thomson, Peter (2000): Brecht and Actor Training: On Whose Behalf Do We Act? In: Hodge, Alison (ed.): Twentieth Century Actor Training. London and New York: Routledge, 98-112

Thomson, Peter \& Sacks, Glendyr (eds.) (2006): The Cambridge Companion to Brecht. Cambridge et al.: Cambridge University Press

Weber, Carl (2006): Brecht and the Berliner Ensemble: The Making of a Model. In: Thomson, Peter \& Sacks, Glendyr (eds): The Cambridge Companion to Brecht. Cambridge, New York, Melbourne: Cambridge University Press, 175-193 
Kramsch, Claire (1996) The Cultural Component of Language Teaching: http://www.spz.tu-darmstadt.de/projekt_ejournal/jjg-01-

2/beitrag/kramsch2.htm

Simpson, John \& Weiner, Edmund (eds.) (1989): The Oxford English

Dictionary, Second Edition, Volume XVI, Soot-Styx. Oxford: Clarendon Press Texts

Online Resource

Dictionary 